\title{
Feeding patterns in the first two years of life in Basra, Iraq
}

Y.S. Benyamen " and M.K. Hassan'

$$
\text { أثناط التغلية في السنتين الأولى والثانية من العمر في البصرة، العراق }
$$

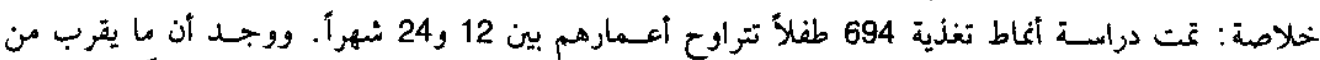

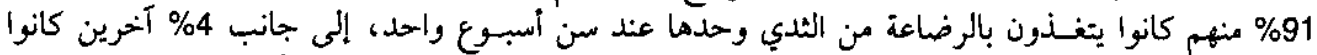

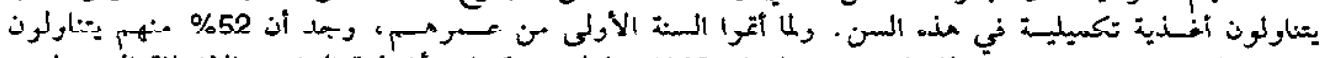

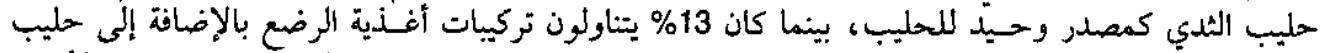

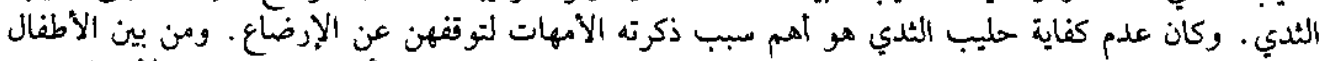

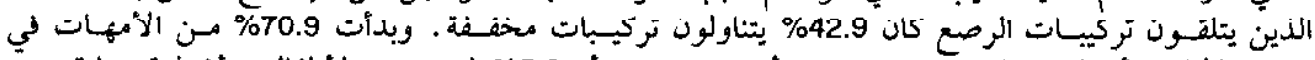

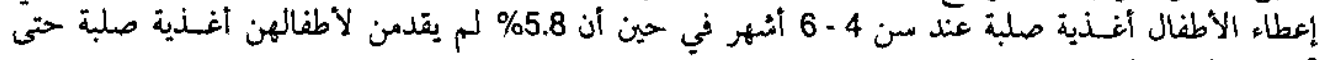
تجاوزوا الشهر الثامن من عمرهم.

ABSTRACT The feeding patterns of 694 children ranging from 12 to 24 months of age were studied. Approximately $91 \%$ were exclusively breast-fed at 1 woek of age with a further $4 \%$ receiving supplementary foods at this stage. At 1 year of age, $52 \%$ were receiving breast milk as the only source of milk and $13 \%$ were receiving infant formula in addition to breast milk. Inadequate breast milk was the most common reason reported by mothers for discontinuing breast-feeding. Of children receiving formula, $42.9 \%$ were receiving diluted formula. $70.9 \%$ of mothers introduced solid foods at 4 to 6 months of age while $5.8 \%$ did not introduce solid foods untif after the age of 8 months.

\section{Modes d'alimentation durant les deux premières années de la vie à Basra (Iraq)}

RESUME Le mode d'alimentation de 694 enfants âgés de 12 à 24 mois a fait l'objet d'une étude. Environ $91 \%$ de ces enfants étaient nourris exclusivement au sein à l'âge d'une semaine, et $4 \%$ d'autres recevaient à cette période des aliments de complément. A l'áge d'un an, $52 \%$ des enfants étaient nourris au sein comme seule source de lait et $13 \%$ étaient alimentés avec des préparations pour nourrissons en complément du lait de leur mère. L'insuffisance du lait maternel etalt la ralson ta plus courante de l'arret de l'allaitement au sein signalée par les mères. Parmi les enfants auxquels l'on donnait une préparation pour nourrissons, $42,9 \%$ prenaient une forme diluée; 70,9\% des mères avaient introduit l'alimentation solide à l'âge de 4-6 mois tandis que 5,8\% ne l'avaient introduite qu'après l'âge de $\theta$ mois.

'Paediatric Department, Basra Medical College, Basra, Iraq.

Received: 06/04/97; accepted: 03/08/97

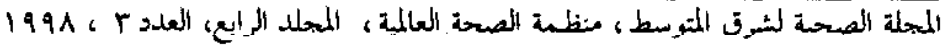




\section{Introduction}

The well-being of the infant depends primarily on the quality and the quantity of food intake. Breast milk is the ideal food to promote growth and to protect against infection in young infants.

Following the decline of breast-feeding in industrialized societies, and its rapid spread to developing countries $[1-3]$, the need to intensify and promote the return to brcast-fecding has becn stated repcatcdly and supported by the World Health Organization (WHO). Since 1978, the WHO and the United Nations Children's Fund (UNICEF) have taken a number of measures of far-reaching importance to proinote, protect and support breast-feeding [4].

Today, international and national efforts are designed to enable every mother at any age and any socioeconomic level to breastfeed her baby exclusively for the initial 4 to 6 months of life. Thereafter, mothers are expected to continue breast-feeding as long as possible, preferably for 2 years, supplementing the child's diet with complementary foods [4]. The purposes of this study were:

- to provide information about the prevalence and duration of breast-feeding;

- to provide information about weaning practices in Basra and to assess the intentions and thoughts of mothers about weaning practices; and

- to compare the recent and previous states of infant feeding patterns in Basra.

\section{Materials and methods}

The study was conducted in 1994 over a period of 2 months ( $A$ pril and May) in two health centres in Basra. The sample studied included 694 mothers who had children between 1 and 2 years of age and who were visiting the health centres for routine vaccinations.

The data were collected using a standard questionnaire designed for the study. It asked the name, age, sex, address and birth order of the child, type of feeding, concentration of milk formula, reasons for discontinuation of breast-feeding, mother's opinion of the most suitable age to start weaning and introduce solid foods, age at introduction of solid food, type of food first given and differences in the feeding practices between oldest and youngest child.

\section{Results and discussion}

The study included 694 children (392 males and 302 females) ranging from 12 to 24 months of age. At the time of interview, 352 children $(50.7 \%)$ were still receiving breast milk as their only source of milk and 100 children ( $14.4 \%$ ) were receiving infant formula in addition to breast milk. In a 1977 study in Baghdad, Abdulli found that only $58.7 \%$ of women used strict breastfeeding during the first 6 months of life and an additional $37.6 \%$ used formula feeding in addition to breast-feeding [5].

This study also showed that approximately $91 \%$ of babies were exclusively breast-fed at 1 week of age, with a further $4 \%$ receiving supplementary feedings at this time. At 1 year of age, $52 \%$ received breast milk exclusively and $13 \%$ received formula in addition to breast milk (Fjgure 1). Mahmood and Feachen (1987) found that $91 \%$ of infants were breast-fed in the furst week of life in Basra and that there was a sharp decline in the rate of exclusive breast-feeding in the first 6 months of life [5]. This increase in the prevalence and du- 


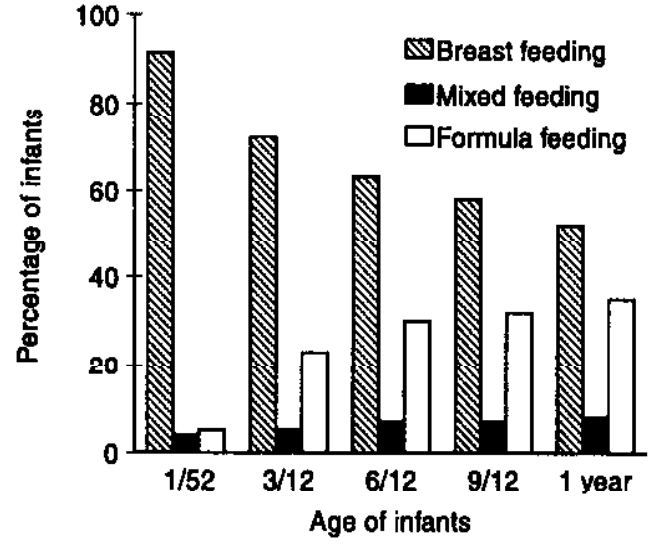

Figure 1 Infant feeding patterns during the first year

ration of breast-feeding may be due to the national programme for the promotion and protection of breast-feeding or due to embargo or both.

Interviews of mothers who had used formula feedings for their infants (342 total) revealed that 147 (about $43.0 \%$ ) of them used diluted formula. This may be due to misunderstandings about formula preparation or due to sanclions innoused on Iray.

Inadequate breast milk was the most common reason, reported by 88 mothers, for discontinuing breast-feeding or for formula feedings in addition to breast-feeding (25.7\%); mother's illness was the second connmun reasun $(22.5 \%$ ) (Table 1 ). Similar results were obtained in previous studies in Iraq $[5,6]$.

About $80 \%$ of mothers had the intention to stop breast-feeding at or after 18 months of age. The same results were obtained in Baghdad more than 40 years ago [2]. In addition, $86.3 \%$ of mothers thought that the most suitable age for introduction of solid food was 4 to 6 months (lable 2) and about $70.9 \%$ introduced solid foods to their children at between 4 and 6 months (Table 3). Table 3 also shows that the earliest age for

\begin{tabular}{|c|c|c|}
\hline Reason & $\begin{array}{r}\text { Mother } \\
\text { No. }\end{array}$ & $\begin{array}{c}=342) \\
\%\end{array}$ \\
\hline \multicolumn{3}{|l|}{ Inadequate breast milk } \\
\hline supply & 88 & 25.7 \\
\hline Sickness of the mother & 77 & 22.5 \\
\hline Subsequent pregnancy & 43 & 12.6 \\
\hline Baby dislikes breast milk & 35 & 10.2 \\
\hline Doctor's advice & 31 & 9.1 \\
\hline Correct time to discontinue & 12 & 3.5 \\
\hline Sickness of the baby & 21 & 6.1 \\
\hline Other & 35 & 10.2 \\
\hline
\end{tabular}

Table 2 Mother's opinions about the most suitable age for introduction of solid food

\begin{tabular}{lrr}
\hline Age (months) & \multicolumn{2}{c}{ Mothers } \\
& No. & \multicolumn{1}{c}{$\%$} \\
\hline 2 & 28 & 4.0 \\
3 & 32 & 4.6 \\
4 & 317 & 45.7 \\
5 & 196 & 28.2 \\
6 & 86 & 12.4 \\
7 & 18 & 2.6 \\
8 & 16 & 2.3 \\
$>8$ & 1 & 0.1 \\
Total & 694 & 99.9 \\
\hline
\end{tabular}

Table 3 Age at which solid foods were introduced

\begin{tabular}{lrc}
\hline Age (months) & No. & $\%$ \\
\hline 3 & 64 & 9.2 \\
4 & 259 & 37.3 \\
5 & 116 & 16.7 \\
6 & 117 & 16.9 \\
7 & 63 & 9.1 \\
8 & 35 & 5.0 \\
$>8$ & 40 & 5.8 \\
Total & 094 & 100 \\
\hline
\end{tabular}


introducing solid food was 3 months and that about $5.8 \%$ of mothers did not introduce solid food until after the age of 8 months.

Biscuits, vegetable soup and rice were the three main types of solid food given as first foods, compared with a 1951 study in which yoghurt, bread and tea were found to be the most common weaning foods [2].

Mothers were asked if they had changed their feeding practices between their oldest children who were born either before 1980 or between 1980 and 1990 and their last child. It was found that while the prevalence of breast-feeding was high in all periods, it increased after 1992. In addition, duration of breast-feeding also increased (Figure 2).

It may be concluded that there is a high prevalence of breast-feeding and an increase in the duration of breast-feeding in comparison with previous studies in Iraq. We hope that the percentage of mothers who fail to breast-feed initially and of those who wean their children early can be minimized or reduced further through public

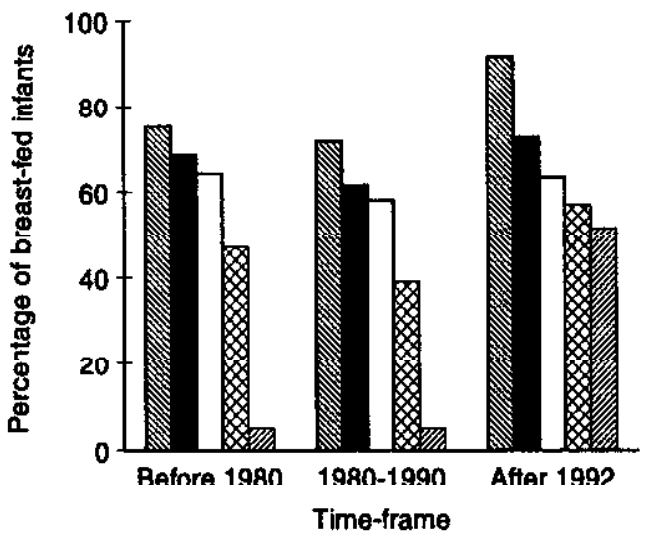

$1 / 52 \square 3 / 12 \square 6 / 12 \square 9 / 12$ ש1 year

Figure 2 Change in teeding patterns between infants born before 1980, 1980-1990 and after 1992

education, social support and a greater awareness on the part of health care workers through the national programme to protect, promote and support breast-feeding and the implementation of baby-friendly hospital initiatives.

\section{References}

1. Sjolin S. Present trends in breast-feeding. Current medical research and opinion, 1976, 4 (suppl. 1):17-22.

2. Jelliffe DB. Infant nutrition in the subtropics and tropics, 2nd ed. WHO Monograph Series, No. 29, 1968.

3. Jolitfo DB, Joliffo EF. Human milk, nutrition and the world resource crisis. Science, 1975, 188:557-61.

4. Hafez $G$, Baghchl $K$. Promoting breastfeeding through $\mathrm{MCH}$ sevices and primary health care. WHO Regional Office for the Eastern Mediterranean, Alexandria, Egypt, 1995:7 (unpublished docu- ment no. WHO-EM/MCH/239-E/G; available from Division of Health Protection and Promotion, WHO EMRO, PO Box 1517, Alexandria 21511).

5. Harfouche JK, Musaiger AO. Breastfeeding patterns. A review of studies in the Eastern Mediterranean Region, 2nd ed. 1993:80-6 (EMRO Technical Publications series, No. 4).

6. Al-Thammery DM. Mohammed H. Kutty R. A pilot enquiry into lactation failure among women in southern Iraq. Basra University medical journal, 1982, 5(1):141-51. 